\title{
Does sample bulk freezing affect stable isotope ratios of infaunal macrozoobenthos?
}

\author{
Jennifer Dannheim $^{\mathrm{a}, *}$, Ulrich Struck ${ }^{\mathrm{b}}$, Thomas Brey ${ }^{\mathrm{a}}$ \\ a Alfred Wegener Institute for Polar and Marine Research, PO Box 120161, 27568 Bremerhaven, Germany \\ ${ }^{\mathrm{b}}$ Museum of Natural History Berlin, Humboldt University, Invalidenstrasse 43, 10115 Berlin, Germany
}

Received 19 September 2006; accepted 5 June 2007

\begin{abstract}
Macrobenthic infaunal sampling campaigns that aim at unpreserved "fresh" animals for later biochemical analysis follow one of two strategies: either samples are sieved and sorted on board and individual specimens are frozen, or grab/corer samples are frozen completely and animals are separated from sediments later in the laboratory. This study demonstrates that deep freezing of complete grab samples causes a significant bias in stable isotope ratios of nitrogen $\left({ }^{15} \mathrm{~N} /{ }^{14} \mathrm{~N}\right.$ or $\delta^{15} \mathrm{~N}$ vs. AIR $)$ and carbon $\left({ }^{13} \mathrm{C} /{ }^{12} \mathrm{C}\right.$ or $\delta^{13} \mathrm{C}$ vs. $\mathrm{PDB}$ ) as well as in the $\mathrm{C} / \mathrm{N}$ ratio of nine infaunal species from the German Bight. On average, molar $\mathrm{C} / \mathrm{N}$ ratio increases by $0.93, \delta^{13} \mathrm{C}$ decreases by $1.87 \%$, and $\delta^{15} \mathrm{~N}$ decreases by $1.01 \%$. Mechanical cell destruction and subsequent loss of cytosol as well as metabolic degradation by free enzymes and by microorganisms are discussed as major causes for the observed effects. We recommend to abstain from using bulk frozen grab samples for the analysis of $\mathrm{C} / \mathrm{N}$ ratio or stable isotope ratios.
\end{abstract}

(C) 2007 Elsevier B.V. All rights reserved.

Keywords: Freezing storage; Infaunal macrozoobenthos; Sample processing; Stable isotopes

\section{Introduction}

Analysis of tissue stable isotope ratios in nitrogen $\left({ }^{15} \mathrm{~N} /{ }^{14} \mathrm{~N}\right.$ or $\delta^{15} \mathrm{~N}$ vs. AIR $)$ and carbon $\left({ }^{13} \mathrm{C} /{ }^{12} \mathrm{C}\right.$ or $\delta^{13} \mathrm{C}$ vs. PDB) is an essential part of modern food web studies in marine benthic communities (e.g. Fry, 1988; Hobson and Welch, 1992; Herman et al., 2000; Jennings et al., 2002). The underlying principle is the enrichment of the heavier isotope ${ }^{15} \mathrm{~N}$ and ${ }^{13} \mathrm{C}$ with each assimilation step in the food chain owing to the selective metabolic loss of

\footnotetext{
* Corresponding author. Tel.: +49 471 48311718; fax: +49 471 48311724.

E-mail address: Jennifer.Dannheim@awi.de (J. Dannheim).
}

the lighter isotopes during food assimilation and growth. On average, fractionation per trophic level amounts to $2.5-5 \%$ in $\delta^{15} \mathrm{~N}$ and to $0-1 \%$ in $\delta^{13} \mathrm{C}$ (De Niro and Epstein, 1978, 1981; Minagawa and Wada, 1984; Post, 2002).

There are many natural sources of variability in stable isotope ratios, but bias owing to sample treatment has drawn a considerable amount of attention recently. Besides sample acidification (Bosley and Wainright, 1999; Jacob et al., 2005; Carabel et al., 2006) and sample lipid extraction (Sweeting et al., 2006), sample storage and preservation appears to be a crucial point. There is a general agreement that oven drying, freezing and freeze drying show little or no effects, whereas formalin and ethanol fixation cause significant bias 
(Bosley and Wainright, 1999; Ponsard and Amlou, 1999; Kaehler and Pakhomov, 2001; Feuchtmayr and Grey, 2003; Lorrain et al., 2003; Sweeting et al., 2004).

In studies on infaunal macrozoobenthic species, the bulk freezing of complete grab/corer samples directly after collection is an appealing approach (e.g. Lovvorn et al., 2005). Separating tiny animals from the sediment and identifying them is a time consuming and laborious task, which can be handled much better in the laboratory than on board of a research vessel with tight restraints on time and space. Here we evaluate whether bulk freezing of complete grab/corer samples and defrosting them again in the laboratory causes bias in stable isotope ratio determinations in animals collected from this sample, and whether such bias is species specific.

\section{Materials and methods}

Infaunal macrozoobenthos was collected with a $0.1 \mathrm{~m}^{2}$ van Veen grab at one site in the German Bight $\left(54^{\circ} 03.83-54^{\circ} 00.96 \mathrm{~N}\right.$ and $006^{\circ} 27.30-006^{\circ} 43.13 \mathrm{E}$, autumn 2004, $R V$ Heincke). Thirteen samples were frozen directly after collection, i.e. the bulk content of the grab was transferred into a polyethylene box and stored at $-20{ }^{\circ} \mathrm{C}$ (bulk freezing, BF). From another 25 samples, we handpicked 91 individuals belonging to nine dominant infaunal species (Echinocardium cordatum, Euspira pulchella, Lanice conchilega, Nephtys sp., Poecilochaetus serpens, Scolelepis bonnieri, Tellimya ferruginosa, Tellina fabula and Urothoe poseido$n i s)$. Each individual was stored separately in a plastic jar at $-20{ }^{\circ} \mathrm{C}$ (individual freezing, IF). After 13 months storage, BF samples were slowly defrosted at $8{ }^{\circ} \mathrm{C}$, and the sediment was removed layer-by-layer following the thawing horizon down into the sample. 77 infaunal specimens were handpicked from the sediment and transferred to cooled seawater $\left(3-4{ }^{\circ} \mathrm{C}\right)$ where they remained for a maximum of $20 \mathrm{~min}$ before further processing. Subsequently, both BF and IF treated samples were lyophilised for $24 \mathrm{~h}$ (Finn-Aqua Lyovac GT2E), homogenized in a ball mill, treated with $1 \mathrm{~mol}^{-1}$ hydrochloric acid (HCL) to eliminate calcium carbonates following the procedure of Jacob et al. (2005), redried at $55^{\circ} \mathrm{C}$ and ground to powder in a mortar.

Stable isotope ratios $\delta^{13} \mathrm{C}$ and $\delta^{15} \mathrm{~N}$ were determined by an isotope-ratio mass spectrometer (Thermo/Finnigan Delta Plus at GeoBioCenter ${ }^{\mathrm{LMU}}$, University of Munich). Gaseous standards ( $\mathrm{N}_{2}$ and $\mathrm{CO}_{2}$ respectively) were calibrated against atmospheric nitrogen (AIR) for nitrogen and the PeeDee Belemite standard (PDB) for carbon. An internal standard (Peptone with known isotope composition) was used for every 6th sample.

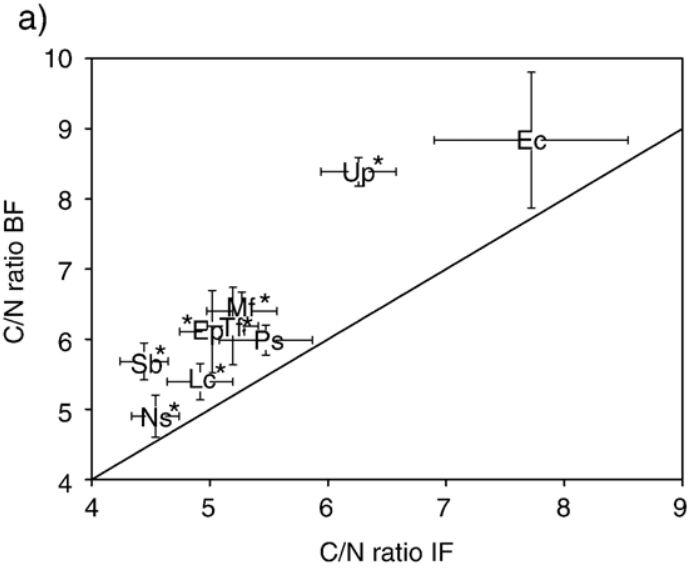

b)

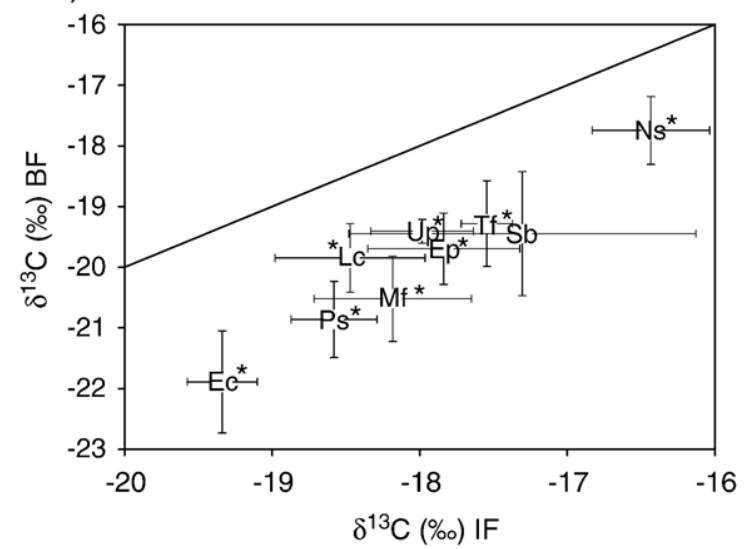

c)

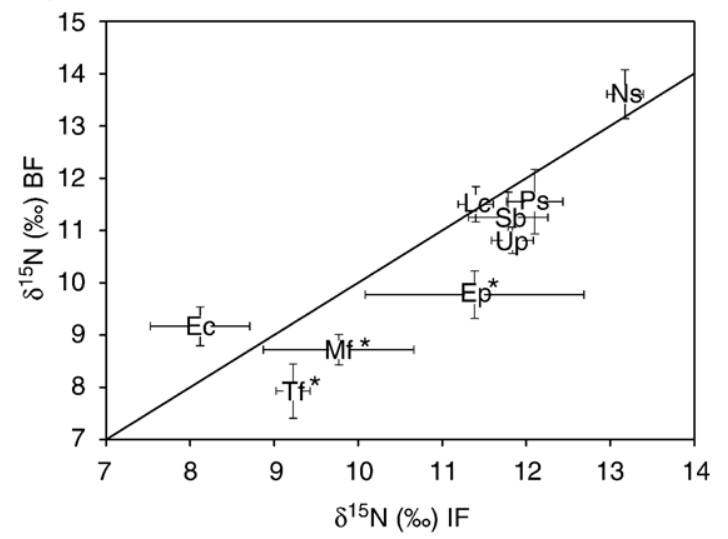

Fig. 1. Plots of (a) $\mathrm{C} / \mathrm{N}$ ratio, (b) $\delta^{13} \mathrm{C}$ and (c) $\delta^{15} \mathrm{~N}$ ratio in bulk treatment $(\mathrm{BF})$ versus individual treatment (IF) samples. Horizontal and vertical bars represent standard deviation of $x$ and $y$ variable for Echinocardium cordatum (Ec), Euspira pulchella (Ep), Lanice conchilega (Lc), Nephtys sp. (Ns), Poecilochaetus serpens (Ps), Scolelepis bonnieri (Sb), Tellimya ferruginosa (Mf), Tellina fabula (Tf). Line indicates 1:1 ratio. *: significant difference between IF and BF in this species as indicated by post-hoc test $(p<0.05)$. 
Table 1

2-way analysis of variance testing the effects of treatment (IF, BF) and species on $\delta^{13} \mathrm{C}, \delta^{15} \mathrm{~N}$ and $\mathrm{C} / \mathrm{N}$ ratio

\begin{tabular}{|c|c|c|c|c|c|c|c|}
\hline \multirow[t]{2}{*}{ Source } & \multirow[t]{2}{*}{$d f$} & \multicolumn{2}{|l|}{$\delta^{13} \mathrm{C}$} & \multicolumn{2}{|l|}{$\delta^{15} \mathrm{~N}$} & \multicolumn{2}{|c|}{$\mathrm{C} / \mathrm{N}$ ratio } \\
\hline & & MS & $F$-value & MS & $F$-value & MS & $F$-value \\
\hline Treatment & 1 & $1.98^{\mathrm{e}-4}$ & $309.34 *$ & 28.69 & $31.50^{*}$ & 0.001 & $215.82^{*}$ \\
\hline Species & 8 & $2.71^{\mathrm{e}-5}$ & $42.36^{*}$ & 178.19 & $195.62 *$ & $3.73^{\mathrm{e}-4}$ & $81.01 *$ \\
\hline Interaction & 8 & $7.47^{\mathrm{e}-7}$ & 1.17 & 10.22 & $11.22^{*}$ & $1.96^{\mathrm{e}-5}$ & $4.26^{*}$ \\
\hline
\end{tabular}

$d f$ : degrees of freedom, MS: mean square; * significant effect with $p<=0.001$.

Experimental precision was $\leq \pm 0.2 \%$. Both isotopes ratios were expressed in $\delta$ notation:

$\delta \mathrm{X}(\% \circ)=\left[\left(R_{\text {sample }} / R_{\text {standard }}\right)-1\right] \times 10^{3}$

where $\delta \mathrm{X}$ is ${ }^{13} \mathrm{C}$ or ${ }^{15} \mathrm{~N}$, and $R$ is the ${ }^{13} \mathrm{C} /{ }^{12} \mathrm{C}$ or ${ }^{15} \mathrm{~N} /{ }^{14} \mathrm{~N}$ ratio.

All samples with $<5 \mu \mathrm{g}$ nitrogen content were excluded from further analysis because of insufficient measurement precision (10 individuals). Multivariate outliers in the sample space $\left[\mathrm{C} / \mathrm{N}, \delta^{15} \mathrm{~N}, \delta^{13} \mathrm{C}\right]$ were identified by Mahalanobis distances (Barnett and Lewis, 1994) and excluded, too (1 individual). Delta ${ }^{13} \mathrm{C}$ data were multiplied by -1 to obtain positive values, and all three data series $\left(\mathrm{C} / \mathrm{N}, \delta^{15} \mathrm{~N},-\delta^{13} \mathrm{C}\right)$ were Box-Cox transformed (Sokal and Rohlf, 1995) in order to achieve normality and equality of variances. Full interaction 2way analysis of variance (ANOVA) followed by posthoc Tukey HSD test on differences between means was applied to check for effects of treatment (IF, BF) and of species on the three parameters.

\section{Results}

Compared to individual freezing (IF), bulk freezing (BF) caused a significant $(p<0.001)$ increase in $\mathrm{C} / \mathrm{N}$ (on average 0.93 , Fig. 1a), and a decrease in both $\delta^{13} \mathrm{C}$ (on average $1.87 \%$, Fig. $1 \mathrm{~b}$ ) and $\delta^{15} \mathrm{~N}$ (on average $1.01 \%$, Fig. 1c). In $\mathrm{C} / \mathrm{N}$ ratio and $\delta^{15} \mathrm{~N}$ ANOVA detected significant interactions between treatment and species (Table 1). On the species level, BF treatment effects were significant in seven (C/N, Fig. 1a), nine $\left(\delta^{13}\right.$ C, Fig. 1b), and three species $\left(\delta^{15} \mathrm{~N}\right.$, Fig. 1c), respectively.

\section{Discussion}

Freezing by itself, i.e. the exposure of organic matter to below zero temperature, has no effect on $\mathrm{C} / \mathrm{N}$ ratio and stable isotope ratios (Bosley and Wainright, 1999; Ponsard and Amlou, 1999; Kaehler and Pakhomov, 2001; Sweeting et al., 2004). There are, however, several distinct differences between the IF and the BF treatment procedure which may affect tissue condition and biochemical properties: (i) The freezing process of a bulk sample takes much longer owing to its larger mass and smaller surface/volume ratio compared to single animals. Slower freezing allows for the formation of more ice crystals inside tissues which can destroy cells mechanically and lead to cell content leakage (Salonen and Sarvala, 1980; Feuchtmayr and Grey, 2003). (ii) Tissues may be damaged further by mechanical stress caused by the antagonistic forces of liquid volume expansion during freezing against sample mass. (iii) Tissue components may be metabolized by free enzymes or by microorganism inhabiting the sediment (e.g. Ponsard and Amlou, 1999), in particular during freezing and thawing of the sample and following mechanical tissue destruction. (iv) Certain macromolecules, in particular fatty acids can be oxidized chemically at temperatures as low as $-30{ }^{\circ} \mathrm{C}(\mathrm{E}$. Brodte, pers. comm.).

The observed increase in $\mathrm{C} / \mathrm{N}$ ratio may be due to either an increase in $\mathrm{C}$ content or a decrease in $\mathrm{N}$ content. Salonen and Sarvala (1980) report a significant leakage of carbon during freezing but do not provide information on the corresponding loss in nitrogen. We presume that mechanical cell destruction during BF treatment leads to a loss of cytosol when thawing. Cytosol has a higher protein content - and thus nitrogen content - than organelles and membranes which are comparatively richer in carbohydrates and in fatty acids (Alberts, 2002).

May cytosol loss following mechanical cell destruction cause the observed decrease in $\delta^{13} \mathrm{C}$ and $\delta^{15} \mathrm{~N}$, too? Feuchtmayr and Grey (2003) compared the effects of various preservation techniques on $\delta^{13} \mathrm{C}$ and $\delta^{15} \mathrm{~N}$ of zooplankton. They relate the observed depletion in the lighter isotopes ${ }^{12} \mathrm{C}$ and ${ }^{14} \mathrm{~N}$ in normally frozen samples $\left(-20^{\circ} \mathrm{C}\right)$ compared to shock frozen (liquid nitrogen) samples to leaching of cell material, too. This would, however, premise that the leached components are lower in $\delta^{13} \mathrm{C}$ and $\delta^{15} \mathrm{~N}$. Distinct molecule groups are known to differ in their isotopic ratios from the average stable isotope composition of the bulk individual (e.g. Peterson and Fry, 1987; Kelly, 2000) but there is no direct evidence yet that e.g. cytosol components are isotopically lighter indeed. 
Besides the physical processes discussed so far, chemical and biochemical activities may play an important role, too, in particular if cells have been damaged mechanically during freezing. Unfortunately, there are numerous potentially significant parameters such as molecule specific isotopic ratios (e.g. Peterson and Fry, 1987; Kelly, 2000), biochemical processes with specific effects on isotopic ratios (Smejkal et al., 1971; Owens, 1987), and decomposition rates specific for certain substrates as well as metabolic pathways (Abraham et al., 1998; Fang et al., 2002; Lyons et al., 2003; Somsamak et al., 2006). Above all, both concentration and composition of sediment microorganisms and free enzymes may change from sample to sample. More sophisticated approaches, e.g. inhibition of free enzymes and/or of microorganisms, or monitoring of dissolved nitrogen and carbon components during sample storage and processing, will enhance our understanding of these processes.

For the time being we can only conclude that sample bulk freezing causes a significant and intolerable bias in the measurements of $\mathrm{C} / \mathrm{N}, \delta^{13} \mathrm{C}$ and $\delta^{15} \mathrm{~N}$.

\section{Acknowledgements}

This study was founded by the European Union within the RESPONSE project (QLRT-2001-00787). We would like to thank Dr. L. Gutow, Dr. E. Brodte, K. Mintenbeck and Dr. A. Schroeder for helpful comments on the manuscript. I. Wosnitza and M. Klein are thanked for their help preparing the samples in the lab, as well as for sorting specimen on board. We also thank the crew of the RV Heincke for their support during the cruise. [SS]

\section{References}

Abraham, W.-R., Hesse, C., Pelz, O., 1998. Ratios of carbon isotopes in microbial lipids as an indicator of substate usage. Appl. Environ. Microbiol. 64, 4202-4209.

Alberts, B., 2002. Molecular Biology of the Cell, 4th ed. Garland Science, New York.

Barnett, V., Lewis, T., 1994. Outliers in Statistical Data, 3rd ed. Wiley, New York.

Bosley, K.L., Wainright, S.C., 1999. Effects of preservatives and acidification on the stable isotope ratios $\left({ }^{15} \mathrm{~N}:{ }^{14} \mathrm{~N},{ }^{13} \mathrm{C}:{ }^{12} \mathrm{C}\right)$ of two species of marine animals. Can. J. Fish. Aquat. Sci. 56, 2181-2185.

Carabel, S., Godínez-Domínguez, E., Verísimo, P., Fernández, L., Freire, J., 2006. An assessment of sample processing methods for stable isotope analyses of marine food webs. J. Exp. Mar. Biol. Ecol. 336, 254-261.

De Niro, M.J., Epstein, S., 1978. Influence of diet on the distribution of carbon isotopes in animals. Geochim. Cosmochim. Acta 42, 495-506.

De Niro, M.J., Epstein, S., 1981. Influence of diet on the distribution of nitrogen isotopes in animals. Geochim. Cosmochim. Acta 45, 341-351.
Fang, J., Barcelona, M.J., Abrajano, T., Nogi, Y., Kato, C., 2002. Isotopic composition of fatty acids of extremely piezophilic bacteria from the Mariana Trench at 11,000 m. Mar. Chem. 80, $1-9$.

Feuchtmayr, H., Grey, J., 2003. Effect of preparation and preservation procedures on carbon and nitrogen stable isotope determinations from zooplankton. Rapid Commun. Mass Spectrom. 17, 2605-2610.

Fry, B., 1988. Food web structure on Georges Bank from stable C, N, and $\mathrm{S}$ isotopic compositions. Limnol. Oceanogr. 33, 1182-1190.

Herman, P.M.J., Middelburg, J.J., Widdows, J., Lucas, C.H., Heip, C.H.R., 2000. Stable isotopes as trophic tracers: combining field sampling and manipulative labelling of food resources for macrobenthos. Mar. Ecol. Prog. Ser. 204, 79-92.

Hobson, K.A., Welch, H.E., 1992. Determination of trophic relationships within a high arctic marine food web using $\delta^{13} \mathrm{C}$ and $\delta^{15} \mathrm{~N}$ analysis. Mar. Ecol. Prog. Ser. 84, 9-18.

Jacob, U., Mintenbeck, K., Brey, T., Knust, R., Beyer, K., 2005. Stable isotope food web studies: a case for standardized sample treatment. Mar. Ecol. Prog. Ser. 287, 251-253.

Jennings, S., Pinnegar, J.K., Polunin, N.V.C., Warr, K.J., 2002. Linking size-based and trophic analyses of benthic community structure. Mar. Ecol. Prog. Ser. 226, 77-85.

Kaehler, S., Pakhomov, E.A., 2001. Effects of storage and preservation on the $\delta^{13} \mathrm{C}$ and $\delta^{15} \mathrm{~N}$ signatures of selected marine organisms. Mar. Ecol. Prog. Ser. 219, 299-304.

Kelly, J.F., 2000. Stable isotopes of carbon and nitrogen in the study of avian and mammalian trophic ecology. Can. J. Zool. 78, 1-27.

Lorrain, A., Savoye, N., Chauvaud, L., Paulet, Y.-M., Naulet, N., 2003. Decarbonation and preservation method for the analysis of organic $\mathrm{C}$ and $\mathrm{N}$ contents and stable isotope ratios of lowcarbonated suspended particulate material. Anal. Chim. Acta 491, $125-133$.

Lovvorn, J.R., Cooper, L.W., Brooks, M.L., de Ruyck, C.C., Bump, J.K., Grebmeier, J.M., 2005. Organic matter pathways to zooplankton and benthos under pack ice in late winter and open water in late summer in the north-central Bering Sea. Mar. Ecol. Prog. Ser. 291, 135-150.

Lyons, T.W., Zhang, C.L., Romanek, C.S., 2003. Introduction isotopic records of microbially mediated processes. Chem. Geol. $195,1-4$.

Minagawa, M., Wada, E., 1984. Stepwise enrichment of ${ }^{15} \mathrm{~N}$ along food chains: further evidence and the relation between $\delta^{15} \mathrm{~N}$ and animal age. Geochim. Cosmochim. Acta 48, 1135-1140.

Owens, N.J.P., 1987. Natural variation in ${ }^{15} \mathrm{~N}$ in the marine environment. Adv. Mar. Biol. 24, 389-451.

Peterson, B.J., Fry, B., 1987. Stable isotopes in ecosystem studies. Ann. Rev. Ecol. Sys. 18, 293-320.

Ponsard, S., Amlou, M., 1999. Effects of several preservation methods on the isotopic content of Drosophila samples. C. R. Acad. Sci., Ser. III 322, 35-41.

Post, D.M., 2002. Using stable isotopes to estimate trophic position: models, methods, and assumptions. Ecology 83, 703-718.

Salonen, K., Sarvala, J., 1980. The effect of different preservation methods on the carbon content of Megacyclops gigas. Hydrobiologia 72, 281-285.

Smejkal, V., Cook, F.D., Krouse, H.R., 1971. Studies of sulphur and carbon isotope fractionation with microorganisms isolated from springs of Western Canada. Geochim. Cosmochim. Acta 35, 787-800.

Sokal, R.R., Rohlf, F.J., 1995. Biometry: the Principles and Practice of Statistics in Biological Research. 3rd ed. Freeman, New York.

Somsamak, P., Richnow, H.H., Häggblom, M.M., 2006. Carbon isotope fractionation during anaerobic degradation of methyl tert- 
butyl ether under sulfate-reducing and methanogenic conditions. Appl. Environ. Microbiol. 72, 1157-1163.

Sweeting, C.J., Polunin, N.V.C., Jennings, S., 2004. Tissue and fixative dependent shifts of $\delta^{13} \mathrm{C}$ and $\delta^{15} \mathrm{~N}$ in preserved ecological material. Rapid Commun. Mass Spectrom. 18, 2587-2592.
Sweeting, C.J., Polunin, N.V.C., Jennings, S., 2006. Effects of chemical lipid extraction and arithmetic lipid correction on stable isotope ratios of fish tissues. Rapid Commun. Mass Spectrom. 20, 595-601. 